\title{
Title: Therapeutic efficacy of CT-P59 against P.1 variant of SARS-CoV-2
}

Dong-Kyun Ryu ${ }^{1}$, Bobin Kang ${ }^{1}$, Sun-Je $\mathrm{Woo}^{2}$, Min-Ho Lee ${ }^{3}$, Aloys SL Tijsma ${ }^{4}$, Hanmi $\mathrm{Noh}^{1}$, Jong-In Kim ${ }^{1}$, Ji-Min Seo ${ }^{1}$, Cheolmin Kim ${ }^{1}$, Minsoo Kim ${ }^{1}$, Eunji Yang ${ }^{2}$, Gippeum $\mathrm{Lim}^{2}$, Seong-Gyu Kim ${ }^{2}$, Su-Kyeong Eo ${ }^{2}$, Jung-ah Choi ${ }^{2}$, Sang-Seok $\mathrm{Oh}^{3}$, Patricia M Nuijten $^{4}$, Manki Song ${ }^{2}$, Hyo-Young Chung ${ }^{3}$, Carel A van Baalen ${ }^{4}$, Ki-Sung Kwon ${ }^{1}$, and Soo-Young Lee ${ }^{1 *}$

${ }^{1}$ Biotechnology Research Institute, Celltrion Inc., Incheon, Republic of Korea.

${ }^{2}$ Science Unit, International Vaccine Institute, Seoul, Republic of Korea.

${ }^{3}$ New Drug Development Center, Osong Medical Innovation Foundation, Cheongju, Republic of Korea.

${ }^{4}$ Viroclinics Biosciences, Rotterdam, The Netherlands.

${ }^{*}$ Corresponding authors:

Soo-Young Lee

20, Academy-ro 51 beon-gil, Yeonsu-gu, Incheon, 22014, South Korea sooyoung.lee@celltrion.com

ORCID ID: 0000-0002-3306-9333 


\section{Highlights}

- CT-P59 could bind to and neutralize P.1 variant, but CT-P59 showed reduced susceptibility in in vitro tests.

- The clinical dosage of CT-P59 demonstrated in vivo therapeutic potency against P.1 variants in hACE2-expressing mice challenge study.

- CT-P59 ameliorates their body weight loss and prevents the lethality in P.1 variant-infected mice. 


\begin{abstract}
P.1. or gamma variant also known as the Brazil variant, is one of the variants of concern (VOC) which appears to have high transmissibility and mortality. To explore the potency of the CT-P59 monoclonal antibody against P.1 variant, we tried to conduct binding affinity, in vitro neutralization, and in vivo animal tests. In in vitro assays revealed that CT-P59 is able to neutralize P.1 variant in spite of reduction in its binding affinity against a RBD (receptor binding domain) mutant protein including K417T/E484K/N501Y and neutralizing activity against P.1 pseudoviruses and live viruses. In contrast, in vivo hACE2 (human angiotensin-converting enzyme 2)-expressing TG (transgenic) mouse challenge experiment demonstrated that a clinically relevant or lower dosages of CT-P59 is capable of lowering viral loads in the respiratory tract and alleviates symptoms such as body weight losses and survival rates. Therefore, a clinical dosage of CT-P59 could compensate for reduced in vitro antiviral activity in P.1-infected mice, implying that CT-P59 has therapeutic potency for COVID-19 patients infected with P.1 variant.
\end{abstract}

\title{
Keywords
}

SARS-CoV-2 virus; P.1, Brazil variant; CT-P59; Regdanvimab; Therapeutic antibody 
bioRxiv preprint doi: https://doi.org/10.1101/2021.07.08.451696; this version posted July 9, 2021. The copyright holder for this preprint (which was not certified by peer review) is the author/funder. All rights reserved. No reuse allowed without permission.

\section{Manuscript}

\section{Introduction}

On November 2021 in Brazil, SARS-CoV-2 infection rapidly increased again in Manaus, where previously showed high sero-prevalences and the newly emerging virus was designated as P.1 or N501Y.V3 [1, 2]. Currently, the P.1 variant become a dominant variant in Brazil and transmitted in many countries [1]. Intriguingly, P.1 variants as well as Delta variant (B.1.617.2) showed rapid displacement of B.1.1.7 in the Unites States [3].

It's known that the P.1 variant possesses 12 amino acid mutations (L18F, T20N, P26S, D138Y, R190S, K417T, E484K, N501Y, D614G, H655Y, T1027I, and V1176F) in the spike protein of SARS-CoV-2 viruses [4]. In particular, three mutations (K417T, E484K, and N501Y) in RBD (Receptor Binding Domain) of P.1 are common in B.1.1.7 (N501Y) and B.1.351 (K417N, E484K, and N501Y) which are associated with increased transmissibility, immune escape and pathogenicity [4-7]. N501Y and E484K mutations in RBD was shown to increase the binding affinity to ACE2 (Angiotensin-Converting Enzyme 2) cellular receptor without any change of spike protein expression level [8]. Moreover, E484K and K417N/K417T mutations were known to reduce COVID-19 vaccine efficacy and confer resistance to some therapeutic monoclonal antibody such as Bamlanivimab or Etesevimab $[4,7,9,10]$. Therefore, P.1 has potential to be rapidly transmissible and resistant to monoclonal antibody therapy as well as vaccines.

The therapeutic monoclonal antibody, CT-P59 which binds to RBD of SARS-CoV-2, interfering with access of ACE2 (Angiotensin-Converting Enzyme 2) receptor for viral infection, has demonstrated that CT-P59 has high potency against the original SARS-CoV-2 in in vitro and in vivo studies with hamster, ferret, and monkey [11]. Previously, we reported that a therapeutic dose of CT-P59 which is relevant to human dosage showed in vivo efficacy against B.1.351 variants in ferret animal model, despite the reduction in in vitro neutralizing 
bioRxiv preprint doi: https://doi.org/10.1101/2021.07.08.451696; this version posted July 9, 2021. The copyright holder for this preprint (which was not certified by peer review) is the author/funder. All rights reserved. No reuse allowed without permission.

activity [12]. Although P.1 has in common with three mutations sites of concern with B.1.351, it remains elusive whether CT-P59 can neutralize P.1 variant. To address this question, we performed in vitro binding, neutralization assays and in vivo challenge experiment in hACE2expressing mice.

\section{Materials and methods}

\subsection{Cells and viruses}

For microneutralization assay, VeroE6 cells (ATCC, CRL-1586) were grown as previously described [12] and Brazil P.1 variant (Isolate hCoV-19/Japan/TY7-503/2021) were obtained through BEI Resources (Catalog No. NR-54982). Derivatives of HEK-293T cells expressing ACE2 were generated by transducing HEK-293T (ATCC, CRL-3216) cells with ACE2 (Addgene, \#145839). Cells were used as single cell clone was derived by limiting dilution from the bulk populations. HEK293T-ACE2 cells were cultured in Dulbecco's modified Eagle's medium (DMEM) supplemented with 10\% (v/v) fetal bovine serum (FBS) and $2 \mathrm{mM}$ penicillin-streptomycin (100 U/mL). K417T, E484K, N501Y, and P.1 pseudoviruses were generated by gene cloning and confirmed by sequencing and Western blot analysis. For in vivo mice challenge study, hCoV-19/Korea/KDCA95637/2021 (P.1) were provided by National Culture Collection for Pathogens (\#43388).

\subsection{Biolayer interferometry (BLI)}

Binding affinity of CT-P59 to wild type and mutant SARS-CoV-2 RBD were evaluated by the Octet $\mathrm{QK}^{\mathrm{e}}$ system (ForteBio) using a modification of a method as previously described [11]. The P.1 triple mutant SARS-CoV-2 RBD (K417T/E484K/N501Y) was purchased from Sino Biological. 
bioRxiv preprint doi: https://doi.org/10.1101/2021.07.08.451696; this version posted July 9, 2021. The copyright holder for this preprint (which was not certified by peer review) is the author/funder. All rights reserved. No reuse allowed without permission.

\subsection{Pseudovirus assay}

Luciferase-based pseudovirus assay was carried out using wild-type and mutant spikeexpressing lentiviruses. Mutations in spike gene were introduced by gene cloning method and its protein expression was confirmed by Western blot analysis. The pseudoviruses were produced by transfection with luciferase reporter plasmid along with Gag-Pol, Rev, and Spike expression plasmid and then the copy number of pseudoviruses was quantitated by qPCR. Pseudoviruses were mixed with diluted antibodies ranging either from 100 to $0.005 \mathrm{ng} / \mathrm{mL}$ or 1000 to $0.05 \mathrm{ng} / \mathrm{ml}$. The inocula infected ACE2-expressing HEK293T cells. After $72 \mathrm{~h}$, luciferase activities were measured and $\mathrm{IC}_{50}$ values were calculated with Prism.

\subsection{Microneutralization (ViroSpot) assay}

To examine the susceptibility of SARS-CoV-2 variants, a microneutralization assay was performed as previously described [12]. Briefly, virus was mixed with serial dilutions CT-P59 and then the virus/CT-P59 mixture was added to Vero E6 cells. After a subsequent incubation, carboxymethylcellulose (CMC) overlay was added. The assay plates were incubated for 16-24 hours. The cells were fixed and permeabilized, followed by treatment with a murine antinucleocapsid monoclonal antibody (Sino Biological), a secondary anti-mouse IgG peroxidase conjugate (Thermo Scientific) and TrueBlue (KPL) substrate. Images of all wells were acquired by a CTL Immunospot analyzer, equipped with Biospot $^{\circledR}$ software to quantitate the nucleocapsid-positive cells.

\subsection{Animal experiments}

8-week-old female human ACE2 transgenic mice, $\operatorname{tg}(\mathrm{K} 18$-ACE2)2Prlmn, were purchased from The Jackson Laboratory (ME, USA). Mice were housed in a certified A/BSL-3 facility at the International Vaccine Institute (IVI). Before virus inoculation, all mice had an 
bioRxiv preprint doi: https://doi.org/10.1101/2021.07.08.451696; this version posted July 9 , 2021. The copyright holder for this preprint (which was not certified by peer review) is the author/funder. All rights reserved. No reuse allowed without permission.

acclimatization period of one week. All procedures were approved by the Institutional Animal Care and Use Committee at the IVI (IACUC Approval No. 2020-021).

\subsection{Mouse study}

Mice ( $\mathrm{n}=11$ /group) were intranasally inoculated with $1 \times 10^{4}$ PFU/30 $\mu \mathrm{L}$ of P.1 variant under anesthesia. After $8 \mathrm{~h}$ virus challenge, four different doses $(5,20,40$, and $80 \mathrm{mg} / \mathrm{kg}$ ) were administered intraperitoneally. Control mice were administered with formulation buffer via the same route. Viral load was measured from nasal wash and lung at 3 dpi or 6 dpi (days post infection), and 4 animals were euthanized at each day for virus quantification. Mortality was recorded from 7 dpi to 10 dpi from three animals per group after final scheduled euthanasia, and body weight of all remaining mice were monitored daily throughout the study period. Animals showing more than $30 \%$ loss of body weight were euthanized and excluded from statistical analysis.

\subsection{Virus titration and quantitation}

To assess SARS-CoV-2 viral loads in the challenged transgenic mice, lung tissues and nasal washes were collected. The lungs from each mouse were aseptically removed and washed with Hank's balanced salt solution containing $1 \%$ penicillin/streptomycin (Thermo Fisher Scientific). The nasal washes from each mouse were collected by flushing with $50 \mu \mathrm{L}$ of sterilized PBS twice through the nasal cavity and stored at $-80^{\circ} \mathrm{C}$ until use. The lung tissues were homogenized and strained through a $70-\mu \mathrm{m}$ cell strainer (Becton Dickinson). The collected supernatants were stored at $-80^{\circ} \mathrm{C}$. The lung samples and nasal washes were 4 -fold serially diluted in DMEM and inoculated to Vero E6 cells in a 12-well plate. After incubation for $30 \mathrm{~min}$, the inoculum was removed and covered with agar-overlay media including $1 \%$ (w/v) low-melting agarose (Lonza) and 2\% FBS in DMEM. Following incubation at $37^{\circ} \mathrm{C}$ for 
bioRxiv preprint doi: https://doi.org/10.1101/2021.07.08.451696; this version posted July 9 , 2021. The copyright holder for this preprint (which was not certified by peer review) is the author/funder. All rights reserved. No reuse allowed without permission.

3 days, the cells were fixed with $4 \%$ (v/v) formaldehyde, and stained with $0.05 \%$ crystal violet (Sigma). The number of plaques per well was counted and analyzed.

\section{Results}

\subsection{In vitro binding affinity and susceptibility tests}

To investigate the therapeutic efficacy of CT-P59 against P.1 variant, we first determined the binding affinity of CT-P59 against triple mutant RBD (K417T/E484K/N501Y) by using BLI (Bio-Layer interferometry). The equilibrium dissociation constant $\left(\mathrm{K}_{\mathrm{D}}\right)$ of CT-P59 against the P.1 triple mutant RBD was reduced by approx. 12-fold compared to that against wild-type RBD (Table 1 and Supplementary Fig. 1). Next, to assess the susceptibility of P.1 variant to CT-P59, we conducted two sorts of cell-based assays with live viruses or pseudotyped viruses. In SARSCoV-2 spike expressing pseudovirus assay, CT-P59 significantly inhibited SARS-CoV-2 D614G pseudovirus with $\mathrm{IC}_{50}$ value of $0.219 \mathrm{ng} / \mathrm{mL}$, but showed approx. 61-fold reduced neutralization of P.1 pseudotyped viruses with an $\mathrm{IC}_{50}$ value of $13.45 \mathrm{ng} / \mathrm{mL}$ (Table 2 and Supplementary Fig. 2A). While CT-P59 showed lower IC $_{50}$ value against K417T mutant pseudovirus than that against D614G, E484K and N501Y was less than 10-fold susceptible to CT-P59, which showed approx. 8.7-fold and 5.5-fold reductions. In addition, the live virus neutralization assay showed approx. 138-fold reduced susceptibility against P.1 variants, compared to that against wild type SARS-CoV-2 (Table 2 and Supplementary Fig. 2B). Thus, we found that CT-P59 is able to neutralize P.1 variants but showed reduced binding and antiviral ability in in vitro experiments.

\subsection{In vivo efficacy of clinical dosages of CT-P59 in mouse model}

To evaluate whether CT-P59 is able to reduce viral loads and protect from exacerbating the infection against P.1 variants in in vivo setting, mice were treated with clinically relevant 
bioRxiv preprint doi: https://doi.org/10.1101/2021.07.08.451696; this version posted July 9 , 2021. The copyright holder for this preprint (which was not certified by peer review) is the author/funder. All rights reserved. No reuse allowed without permission.

dosages considering the $40 \mathrm{mg} / \mathrm{kg}$ of clinical dose of CT-P59. The dose of $80 \mathrm{mg} / \mathrm{kg}$ was selected by equivalent exposure in mice to that of clinical study (data not shown), and lower doses of 5 and $20 \mathrm{mg} / \mathrm{kg}$ were additionally selected for further investigation with the lower exposure than the clinical situation. P.1 variants severely affected the survival rate of control animals resulting in $0 \%$ survival rate at 8 dpi (days post-infection), having two mice euthanized which showed more than $30 \%$ body weight loss at $7 \mathrm{dpi}$ and one mouse died at $8 \mathrm{dpi}$. In contrast, no death or over $30 \%$ loss of body weight was observed in all CT-P59 treatment groups throughout the study period (Fig. 1 A). Following infection with P.1 variants, body weights were significantly not altered in CT-P59 treatment groups. In contrast, the control groups infected by P.1 only lose the body weight since 1 dpi, resulting in severely decreased mean body weights and eventually $28.4 \%$ loss at 7 dpi. Importantly, the CT-P59 treatment delayed statistically significant loss of their body weight compared to control mice from 2 dpi to 6 dpi. CT-P59 treatment groups at 5, 20, 40 and $80 \mathrm{mg} / \mathrm{kg}$ showed 18.8, 16.6, 16.7 and 9.2\% loss of mean body weight at 6 dpi, respectively. However, the mean body weight of 20, 40 and 80 $\mathrm{mg} / \mathrm{kg}$ CT-P59 treatment groups began to revitalize from 6 dpi and fully recovered at $10 \mathrm{dpi}$ (Fig. 1 B). To monitor viral loads in upper and lower respiratory tracts, we performed plaque assay with mice lung and nasal wash samples. CT-P59 treatment effectively reduced the infectious virus titers in lung tissues and nasal washes of the mice challenged with P.1 variants. The mean virus titer in lung tissues reached $5.1 \log (\mathrm{PFU}+1) / \mathrm{mL}$ at $3 \mathrm{dpi}$ and declined to 2.4 $\log (\mathrm{PFU}+1) / \mathrm{mL}$ at $6 \mathrm{dpi}$ in the control group. In contrast, all CT-P59 animals had reduced viral titers at 3 dpi and 6 dpi. At 3 dpi, infectious viral titers were 9.2, 5.5, 2.5 and 3.6-fold log reduced in 5, 20, 40 and $80 \mathrm{mg} / \mathrm{kg}$ CT-P59 treatment groups respectively, compared to the control group; complete diminution were observed in lungs from 3 out of 4 animals in 5, 20 and $80 \mathrm{mg} / \mathrm{kg}$ treatment groups. At $6 \mathrm{dpi}$, no viral titers were detected in all CT-P59 treatment groups showing a complete reduction of infectious viruses (Fig $1 \mathrm{C}$ and D). In upper respiratory 
bioRxiv preprint doi: https://doi.org/10.1101/2021.07.08.451696; this version posted July 9 , 2021. The copyright holder for this preprint (which was not certified by peer review) is the author/funder. All rights reserved. No reuse allowed without permission.

tracts, the mean virus titers from nasal washes reached $0.5 \log (\mathrm{PFU}+1) / \mathrm{mL}$ at $3 \mathrm{dpi}$ and showed a value of $0.6 \log (\mathrm{PFU}+1) / \mathrm{mL}$ at 6 dpi in the control group; one mouse from control group showed viral loads of $2 \log (\mathrm{PFU}+1) / \mathrm{mL}$ or above at 3 dpi and $6 \mathrm{dpi}$, respectively. On the contrary, no infectious viruses were measured in all CT-P59 treated groups at 3 dpi and 6 dpi, in line with lower respiratory tracts as stated above (Fig. $1 \mathrm{E}$ and F).

\section{Discussion}

In this study, as with previous report on B.1.351 [12], we demonstrated that the therapeutic effect of CT-P59 against the P.1 variant of SARS-CoV-2 by in vitro neutralization tests and in vivo challenge experiments using hACE2 transgenic mice. Although P.1 share common mutation locations at K417, E484, and N501, the neutralization against P.1 was observed to differ from that on B.1.351 as mention above, since CT-P59 showed 61-fold and 138-fold reduced neutralizing activity against P.1 with the pseudovirus assay and micro-neutralization assay, respectively. Therefore, substitution or deletion mutations in the other regions such as NTD (N-terminal domain) or S2 except RBD in P.1 or B.1.351 variant could contribute to change in conformation of spike protein, potentially impacting the neutralization of therapeutic antibodies.

In previous report, B.1.351 known as South African variant or beta variant showed 20-fold and 33-fold reduced susceptibility to CT-P59 by micro-neutralization assay and pseudovirus assay, respectively. However, a therapeutic dosage of CT-P59 which corresponds to clinical dosage for patient treatment has inhibitory effect on replication of B.1.351 in the ferret challenge model to a similar extent to replication of wild type virus. Afterwards, we found that CT-P59 showed 1.8-fold stronger antiviral effect on B.1.1.7 variants than wild type and 310-fold reduced 
bioRxiv preprint doi: https://doi.org/10.1101/2021.07.08.451696; this version posted July 9 , 2021. The copyright holder for this preprint (which was not certified by peer review) is the author/funder. All rights reserved. No reuse allowed without permission.

neutralizing activity against B.1.351 isolated from patients in South Korea in plaque reduction neutralization test, but we confirmed the neutralizing effect of clinically relevant and lower doses of CT-P59 in B.1.351-infected hACE2-expressing mice (unpublished results). Along with P.1 data, we speculate that a clinical dosage of CT-P59 (40 mg/kg in human patients) would be able to overcome $138 \sim 310$-fold reduction in in vitro antiviral activity.

In parallel, we determined the in vivo neutralizing potency of CT-P59 against P.1 variant in the hACE2 TG mouse model. K18-hACE TG mice model was known to be susceptible to SARSCoV-2 and develop severe clinical symptoms of COVID-19 disease [13, 14]. Although ferrets infected by wild type or B.1.351 showed lower viral titers in the lower airway compared to the upper airway [11], we found that the virus titers of P.1 variants remained lower in the upper respiratory tract than in the lower respiratory tract in the mice. These results were not surprising because K18-hACE TG mice are highly susceptible to SARS-CoV-2 infection and experience higher viral titers in lung tissues compared to the upper respiratory tract [15]. In line with this finding, a recent report showed that P.1 variant-infected common laboratory mice resulted in high viral titers in lung tissues [16]. However, neither body weight loss nor lethality was observed in wild mice challenged with P.1 variants on the contrary to our results which manifest a severe body weight loss in the control group. Given that unmodified animals infected with P.1 variants showed anatomical and histopathological changes in the lower respiratory tract [17], our findings that CT-P59 treatment led to complete reduction of infectious viruses, full recovery of body weight loss, and no death rates provide us with expectation to alleviate additional pneumonia as well as virus infections, although no pathological data were available in this study. 
bioRxiv preprint doi: https://doi.org/10.1101/2021.07.08.451696; this version posted July 9 , 2021. The copyright holder for this preprint (which was not certified by peer review) is the author/funder. All rights reserved. No reuse allowed without permission.

\section{Conclusion}

The in vitro and in vivo studies demonstrate that clinical dosages of CT-P59 which corresponds to human dose for patients and lower doses, showed significant reduction in viral loads and protection from worsening of symptoms in P.1-infected mice despite the reduced in vitro potency of CT-P59 against P.1 variants.

\section{Declaration of competing interest}

The authors declare that they have no known competing financial interests or personal relationships that could have appeared to influence the work reported in this paper

\section{Acknowledgements}

This research did not receive any specific grant from funding agencies in the public, commercial, or not-for-profit sectors.

\section{References}

[1] N.R. Faria, T.A. Mellan, C. Whittaker, I.M. Claro, D.D.S. Candido, S. Mishra, M.A.E. Crispim, F.C.S. Sales, I. Hawryluk, J.T. McCrone, R.J.G. Hulswit, L.A.M. Franco, M.S. Ramundo, J.G. de Jesus, P.S. Andrade, T.M. Coletti, G.M. Ferreira, C.A.M. Silva, E.R. Manuli, R.H.M. Pereira, P.S. Peixoto, M.U.G. Kraemer, N. Gaburo, Jr., C.D.C. Camilo, H. Hoeltgebaum, W.M. Souza, E.C. Rocha, L.M. de Souza, M.C. de Pinho, L.J.T. Araujo, F.S.V. Malta, A.B. de Lima, J.D.P. Silva, D.A.G. Zauli, A.C.S. Ferreira, R.P. Schnekenberg, D.J. Laydon, P.G.T. Walker, H.M. Schluter, A.L.P. Dos Santos, M.S. Vidal, V.S. Del Caro, R.M.F. Filho, H.M. Dos Santos, R.S. Aguiar, J.L. Proenca-Modena, B. Nelson, J.A. Hay, M. Monod, X. Miscouridou, H. Coupland, R. Sonabend, M. Vollmer, A. Gandy, C.A. Prete, Jr., V.H. Nascimento, M.A. Suchard, T.A. Bowden, S.L.K. Pond, C.H. Wu, O. Ratmann, N.M. Ferguson, C. Dye, N.J. Loman, P. Lemey, A. Rambaut, N.A. Fraiji, M. Carvalho, O.G. Pybus, S. Flaxman, S. Bhatt, E.C. Sabino, Genomics and epidemiology of the P.1 SARS-CoV-2 lineage in Manaus, Brazil, Science, 372 (2021) 815-821.

[2] L.F. Buss, C.A. Prete, Jr., C.M.M. Abrahim, A. Mendrone, Jr., T. Salomon, C. de Almeida-Neto, R.F.O. Franca, M.C. Belotti, M. Carvalho, A.G. Costa, M.A.E. Crispim, S.C. Ferreira, N.A. Fraiji, S. Gurzenda, C. Whittaker, L.T. Kamaura, P.L. Takecian, P. da Silva Peixoto, M.K. Oikawa, A.S. Nishiya, V. Rocha, N.A. Salles, A.A. de Souza Santos, M.A. da Silva, B. Custer, K.V. Parag, M. Barral-Netto, M.U.G. Kraemer, R.H.M. Pereira, O.G. Pybus, M.P. Busch, M.C. Castro, C. Dye, V.H. Nascimento, N.R. Faria, E.C. Sabino, Three-quarters attack rate of SARS-CoV-2 in the Brazilian Amazon during a largely unmitigated epidemic, Science, 371 (2021) 288-292. 
[3] E.T.C. Alexandre Bolze, Shishi Luo1, Simon White1, Dana Wyman, Andrew Dei Rossi, Tyler Cassens, Sharoni Jacobs, Jason Nguyen, Jimmy M. Ramirez III, Efren Sandoval, Xueqing Wang, David Wong, David Becker, Marc Laurent, James T. Lu, Magnus Isaksson, Nicole L. Washington, William Lee, Rapid displacement of SARS-CoV-2 variant B.1.1.7 by B.1.617.2 and P.1 in the United States., medRxiv, (2021).

[4] W. Dejnirattisai, D. Zhou, P. Supasa, C. Liu, A.J. Mentzer, H.M. Ginn, Y. Zhao, H.M.E. Duyvesteyn, A. Tuekprakhon, R. Nutalai, B. Wang, C. Lopez-Camacho, J. Slon-Campos, T.S. Walter, D. Skelly, S.A. Costa Clemens, F.G. Naveca, V. Nascimento, F. Nascimento, C. Fernandes da Costa, P.C. Resende, A. Pauvolid-Correa, M.M. Siqueira, C. Dold, R. Levin, T. Dong, A.J. Pollard, J.C. Knight, D. Crook, T. Lambe, E. Clutterbuck, S. Bibi, A. Flaxman, M. Bittaye, S. BelijRammerstorfer, S.C. Gilbert, M.W. Carroll, P. Klenerman, E. Barnes, S.J. Dunachie, N.G. Paterson, M.A. Williams, D.R. Hall, R.J.G. Hulswit, T.A. Bowden, E.E. Fry, J. Mongkolsapaya, J. Ren, D.I. Stuart, G.R. Screaton, Antibody evasion by the P.1 strain of SARS-CoV-2, Cell, 184 (2021) 29392954 e2939.

[5] A.F. Martins, A.P. Zavascki, P.L. Wink, F.C.Z. Volpato, F.L. Monteiro, C. Rosset, F. De-Paris, A.K. Ramos, A.L. Barth, Detection of SARS-CoV-2 lineage P.1 in patients from a region with exponentially increasing hospitalisation rate, February 2021, Rio Grande do Sul, Southern Brazil, Euro Surveill, 26 (2021).

[6] G. Hahn, C.M. Wu, S. Lee, S.M. Lutz, S. Khurana, L.R. Baden, S. Haneuse, D. Qiao, J. Hecker, D.L. DeMeo, R.E. Tanzi, M.C. Choudhary, B. Etemad, A. Mohammadi, E. Esmaeilzadeh, M.H. Cho, J.Z. Li, A.G. Randolph, N.M. Laird, S.T. Weiss, E.K. Silverman, K. Ribbeck, C. Lange, Genomewide association analysis of COVID-19 mortality risk in SARS-CoV-2 genomes identifies mutation in the SARS-CoV-2 spike protein that colocalizes with P.1 of the Brazilian strain, Genet Epidemiol, (2021).

[7] P. Wang, R.G. Casner, M.S. Nair, M. Wang, J. Yu, G. Cerutti, L. Liu, P.D. Kwong, Y. Huang, L. Shapiro, D.D. Ho, Increased resistance of SARS-CoV-2 variant P.1 to antibody neutralization, Cell Host Microbe, 29 (2021) 747-751 e744.

[8] T.N. Starr, A.J. Greaney, S.K. Hilton, D. Ellis, K.H.D. Crawford, A.S. Dingens, M.J. Navarro, J.E. Bowen, M.A. Tortorici, A.C. Walls, N.P. King, D. Veesler, J.D. Bloom, Deep Mutational Scanning of SARS-CoV-2 Receptor Binding Domain Reveals Constraints on Folding and ACE2 Binding, Cell, 182 (2020) 1295-1310 e1220.

[9] T.N. Starr, A.J. Greaney, A.S. Dingens, J.D. Bloom, Complete map of SARS-CoV-2 RBD mutations that escape the monoclonal antibody LY-CoV555 and its cocktail with LY-CoV016, Cell Rep Med, 2 (2021) 100255.

[10] M. Hoffmann, P. Arora, R. Gross, A. Seidel, B.F. Hornich, A.S. Hahn, N. Kruger, L. Graichen, H. Hofmann-Winkler, A. Kempf, M.S. Winkler, S. Schulz, H.M. Jack, B. Jahrsdorfer, H.

Schrezenmeier, M. Muller, A. Kleger, J. Munch, S. Pohlmann, SARS-CoV-2 variants B.1.351 and P.1 escape from neutralizing antibodies, Cell, 184 (2021) 2384-2393 e2312.

[11] C. Kim, D.K. Ryu, J. Lee, Y.I. Kim, J.M. Seo, Y.G. Kim, J.H. Jeong, M. Kim, J.I. Kim, P. Kim, J.S. Bae, E.Y. Shim, M.S. Lee, M.S. Kim, H. Noh, G.S. Park, J.S. Park, D. Son, Y. An, J.N. Lee, K.S. Kwon, J.Y. Lee, H. Lee, J.S. Yang, K.C. Kim, S.S. Kim, H.M. Woo, J.W. Kim, M.S. Park, K.M. Yu, S.M. Kim, E.H. Kim, S.J. Park, S.T. Jeong, C.H. Yu, Y. Song, S.H. Gu, H. Oh, B.S. Koo, J.J. Hong, C.M. Ryu, W.B. Park, M.D. Oh, Y.K. Choi, S.Y. Lee, A therapeutic neutralizing antibody targeting receptor binding domain of SARS-CoV-2 spike protein, Nat Commun, 12 (2021) 288.

[12] D.K. Ryu, R. Song, M. Kim, Y.I. Kim, C. Kim, J.I. Kim, K.S. Kwon, A.S. Tijsma, P.M. Nuijten, C.A. van Baalen, T. Hermanus, P. Kgagudi, T. Moyo-Gwete, P.L. Moore, Y.K. Choi, S.Y. Lee, Therapeutic effect of CT-P59 against SARS-CoV-2 South African variant, Biochem Biophys Res Commun, 566 (2021) 135-140.

[13] L. Bao, W. Deng, B. Huang, H. Gao, J. Liu, L. Ren, Q. Wei, P. Yu, Y. Xu, F. Qi, Y. Qu, F. Li, Q. Lv, W. Wang, J. Xue, S. Gong, M. Liu, G. Wang, S. Wang, Z. Song, L. Zhao, P. Liu, L. Zhao, F. Ye, H. Wang, W. Zhou, N. Zhu, W. Zhen, H. Yu, X. Zhang, L. Guo, L. Chen, C. Wang, Y. Wang, X. Wang, Y. Xiao, Q. Sun, H. Liu, F. Zhu, C. Ma, L. Yan, M. Yang, J. Han, W. Xu, W. Tan, X. Peng, Q. 
bioRxiv preprint doi: https://doi.org/10.1101/2021.07.08.451696; this version posted July 9 , 2021. The copyright holder for this preprint (which was not certified by peer review) is the author/funder. All rights reserved. No reuse allowed without permission.

Jin, G. Wu, C. Qin, The pathogenicity of SARS-CoV-2 in hACE2 transgenic mice, Nature, 583 (2020) 830-833.

[14] Y. Wan, J. Shang, R. Graham, R.S. Baric, F. Li, Receptor Recognition by the Novel Coronavirus from Wuhan: an Analysis Based on Decade-Long Structural Studies of SARS Coronavirus, J Virol, 94 (2020).

[15] C.K. Yinda, J.R. Port, T. Bushmaker, I. Offei Owusu, J.N. Purushotham, V.A. Avanzato, R.J. Fischer, J.E. Schulz, M.G. Holbrook, M.J. Hebner, R. Rosenke, T. Thomas, A. Marzi, S.M. Best, E. de Wit, C. Shaia, N. van Doremalen, V.J. Munster, K18-hACE2 mice develop respiratory disease resembling severe COVID-19, PLoS Pathog, 17 (2021) e1009195.

[16] M.P. Xavier Montagutelli, Laurine Levillayer, Eduard Baquero Salazar, Grégory Jouvion, Laurine Conquet, Flora Donati, Mélanie Albert, Fabiana Gambaro, Sylvie Behillil, Vincent Enouf, Dominique Rousset, Jean Jaubert, Felix Rey, Sylvie van der Werf, Etienne Simon-Loriere, The B1.351 and P.1 variants extend SARS-CoV-2 host range to mice, bioRixv, (2021).

[17] P.J.H. Masaki Imaia, Seiya Yamayoshia, Kiyoko Iwatsuki-Horimotoa, Shiho Chibab, Tokiko Watanabea, Noriko Nakajimad, Mutsumi Itoa, Makoto Kurodab, Maki Kisoa, Tadashi Maemuraa, Kenta Takahashid, Samantha Loebere, Masato Hattab, Michiko Kogaf, Hiroyuki Nagaig, Shinya Yamamoto, Makoto Saito, Eisuke Adachi, Osamu Akasaka, Morio Nakamura, Ichiro Nakachi, Takayuki Ogura, Rie Baba, Kensuke Fujita, Junichi Ochi, Keiko Mitamura, Hideaki Kato, Hideaki Nakajima, Kazuma Yagi, Shin-ichiro Hattori, Kenji Maeda, Tetsuya Suzuki, Yusuke Miyazato, Riccardo Valdez, Carmen Gherasim, Yuri Furusawa, Moe Okuda, Michiko Ujie, Tiago J. S. Lopes, Atsuhiro Yasuhara, Hiroshi Ueki, Yuko Sakai-Tagawa, Amie J. Eisfeld, John J. Baczenas, David A. Baker, Shelby L. O'Connor, David H. O'Connor, Shuetsu Fukushi, Tsuguto Fujimoto, Yudai Kuroda, Aubree Gordon, Ken Maeda, Norio Ohmagari, Norio Sugaya, Hiroshi Yotsuyanagi, Hiroaki Mitsuya, Tadaki Suzuki, and Yoshihiro Kawaoka, Characterization of a new SARS-CoV-2 variant that emerged in Brazil, PNAS, 118 (2021) e2106535118. 
bioRxiv preprint doi: https://doi.org/10.1101/2021.07.08.451696; this version posted July 9, 2021. The copyright holder for this preprint (which was not certified by peer review) is the author/funder. All rights reserved. No reuse allowed without permission.

\section{Figure/Table Legends}

Table 1. Binding affinity between CT-P59 and P.1 mutant RBD

\begin{tabular}{cccccc}
\hline Ligand & Analyte & $\mathrm{k}_{\mathrm{On}}\left(\mathrm{M}^{-1} \mathrm{~s}^{-1}\right)$ & $\mathrm{k}_{\mathrm{Off}}\left(\mathrm{s}^{-1}\right)$ & $\mathrm{K}_{\mathrm{D}}(\mathrm{M})$ & Fold change \\
\hline RBD (wild-type) & CT-P59 & $9.32 \mathrm{E}+05$ & $5.89 \mathrm{E}-05$ & $6.32 \mathrm{E}-11$ & - \\
\hline K417T/E484K/N501Y & CT-P59 & $6.80 \mathrm{E}+05$ & $5.23 \mathrm{E}-04$ & $7.69 \mathrm{E}-10$ & 12 (reduction) \\
\hline
\end{tabular}

Table 2. Neutralization effect of CT-P59 against P.1 live viruses and P.1 pseudoviruses

\begin{tabular}{ccc}
\hline Viruses & $\mathrm{IC}_{50}(\mathrm{ng} / \mathrm{mL})$ & Fold change (reduction) \\
\hline P.1 (live virus) & $275.75(\mathrm{WT}: 2.0)$ & 137.86 \\
P.1 (Pseudovirus) & $13.45(\mathrm{D} 614 \mathrm{G}: 0.219)$ & 61.42 \\
K417T & $0.154(\mathrm{D} 614 \mathrm{G}: 0.219)$ & 0.70 \\
E484K & $3.273(\mathrm{D} 614: 0.378)$ & 8.66 \\
$\mathrm{~N} 501 \mathrm{Y}$ & $1.202(\mathrm{D} 614 \mathrm{G}: 0.219)$ & 5.49 \\
\hline
\end{tabular}

A

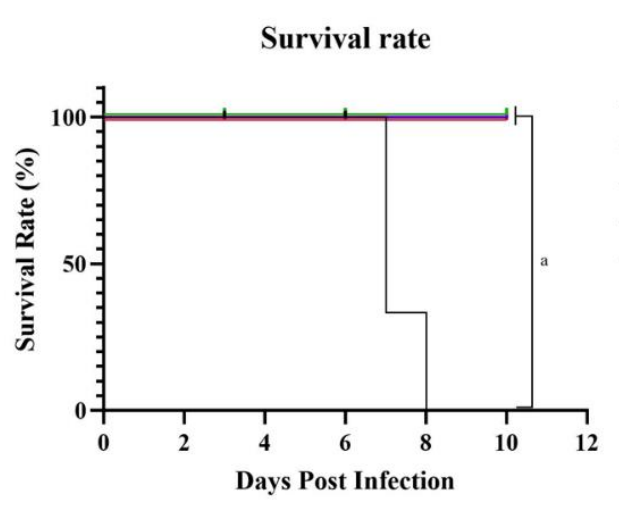

$\mathbf{B}$

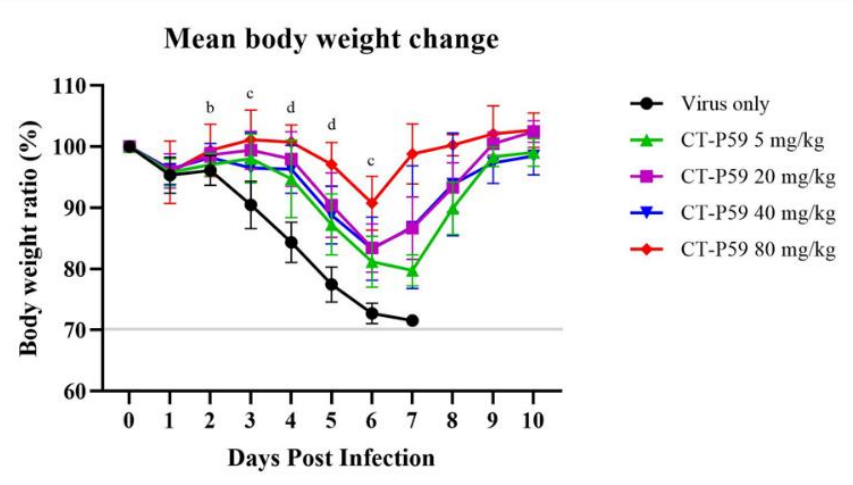


C

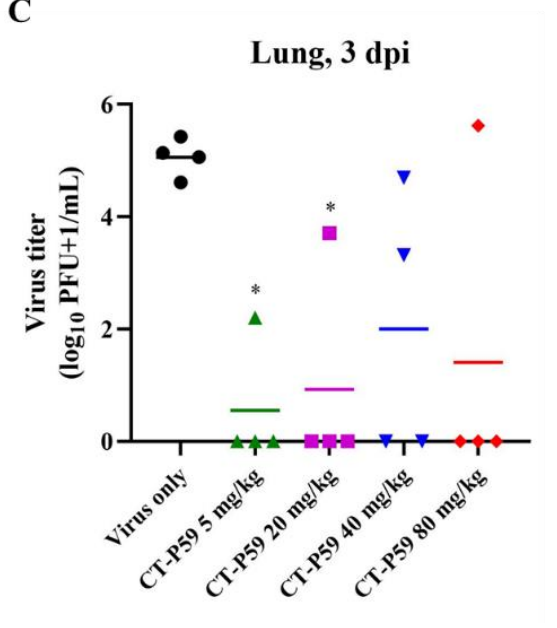

$\mathbf{E}$

Nasal wash, 3 dpi

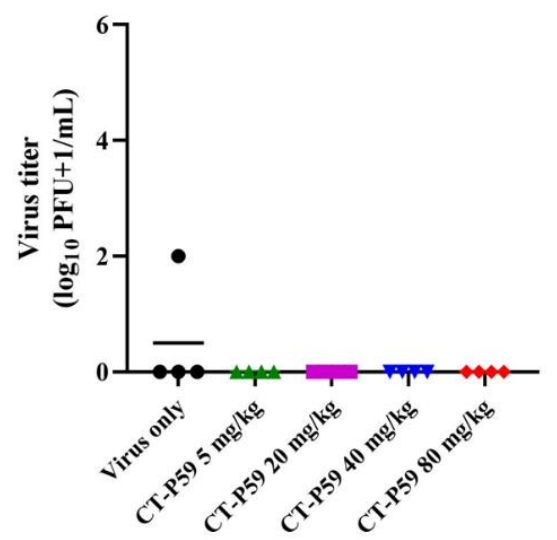

D

Lung, 6 dpi

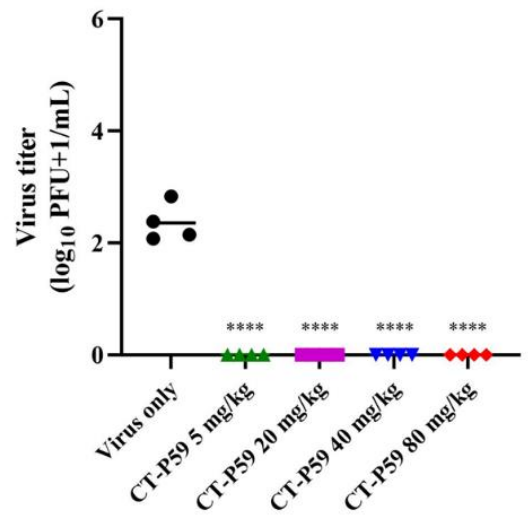

F
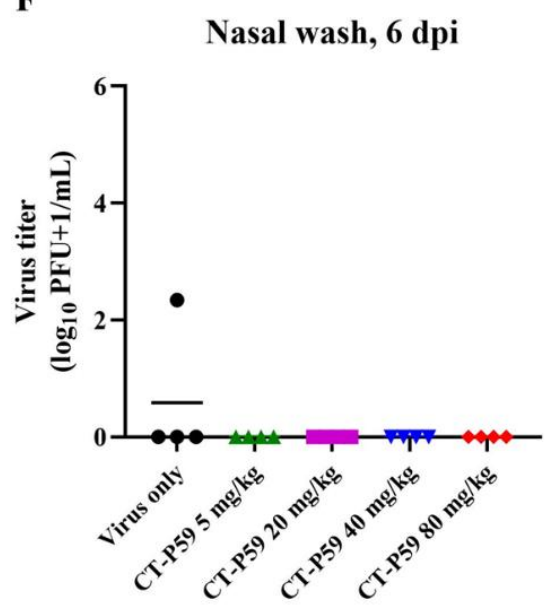

Figure 1. In vivo efficacy of CT-P59 against P.1 variant in transgenic mouse model.

Human ACE2 Transgenic mice (n=11/group) were challenged with $10^{4}$ PFU of P.1 variants. Vehicle and 5, 20, 40 and $80 \mathrm{mg} / \mathrm{kg}$ of CT-P59 were administered intraperitoneally $8 \mathrm{~h}$ after virus inoculation. Body weights and survival rates were monitored daily until $10 \mathrm{dpi}$ (A, B). 30\% or higher of weight loss was considered to be dead. Four animals each were euthanized for virus titration at 3 dpi and 6 dpi. The virus titers from lung tissue and nasal wash were measured (C, D, E, F) using plaque assay. Alphabets and asterisks indicates statistical significance between the control and each groups as determined by one-way ANOVA followed by a Dunnett's post-hos test. $a$ denotes $\mathrm{p}<0.0001$ between control and CTP59 treatment groups (pooled). $b$ denotes $\mathrm{p}<0.01$ to $\mathrm{p}<0.05$ between control and CT-P59 treatment group at $80 \mathrm{mg} / \mathrm{kg}$. $c$ denotes $\mathrm{p}<0.0001$ to $\mathrm{p}<0.01$ between control and CT-P59 treatment groups at 5 , 
bioRxiv preprint doi: https://doi.org/10.1101/2021.07.08.451696; this version posted July 9, 2021. The copyright holder for this preprint (which was not certified by peer review) is the author/funder. All rights reserved. No reuse allowed without permission.

20,40 and $80 \mathrm{mg} / \mathrm{kg}$. $d$ denotes $\mathrm{p}<0.0001$ to $\mathrm{p}<0.001$ between control and CT-P59 treatment groups at 5, 20, 40 and $80 \mathrm{mg} / \mathrm{kg}$. * indicates $P<0.05$, and $* * * *$ indicates $P<0.0001$. 


\section{Supplementary Material}

A

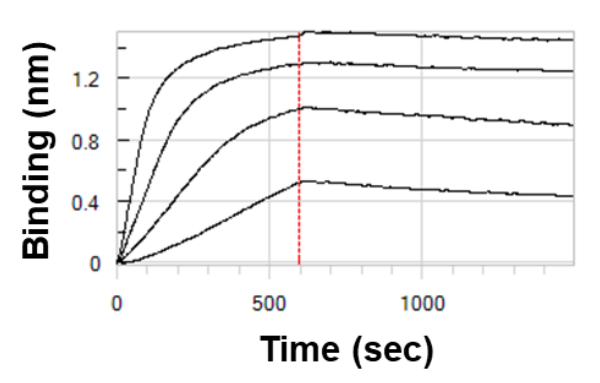

B

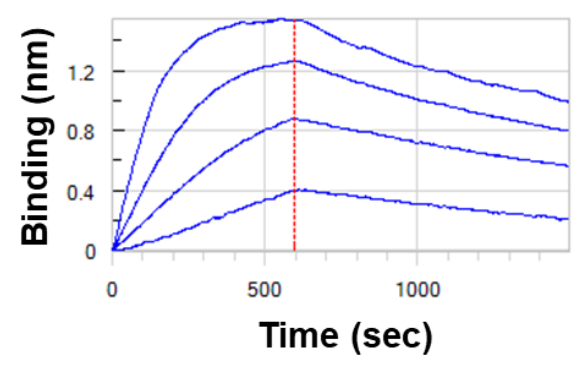

Supplementary figure 1. BLI sensorgrams for the evaluation of CT-P59 binding affinity against wild-type RBD and P.1 triple mutant RBD.

SARS-CoV-2 wild-type RBD (A) or P.1 triple mutant RBD (B) was loaded and immobilized onto AntiPenta-His (HIS1K) Biosensor (Sartorius) at the concentration of $50 \mathrm{nM}$ for $7.5 \mathrm{~min}$, and then CT-P59 was flowed with the concentration of $10 \mathrm{nM}, 5 \mathrm{nM}, 2.5 \mathrm{nM}$ and $1.25 \mathrm{nM}$ for $10 \mathrm{~min}$ and $15 \mathrm{~min}$ to generate association and dissociation curve, respectively. BLI experiment was operated using Octet Data Acquisition v11.0 software (ForteBio), and calculation of binding affinity was performed with ForteBio Data Analysis v11.0. 
A
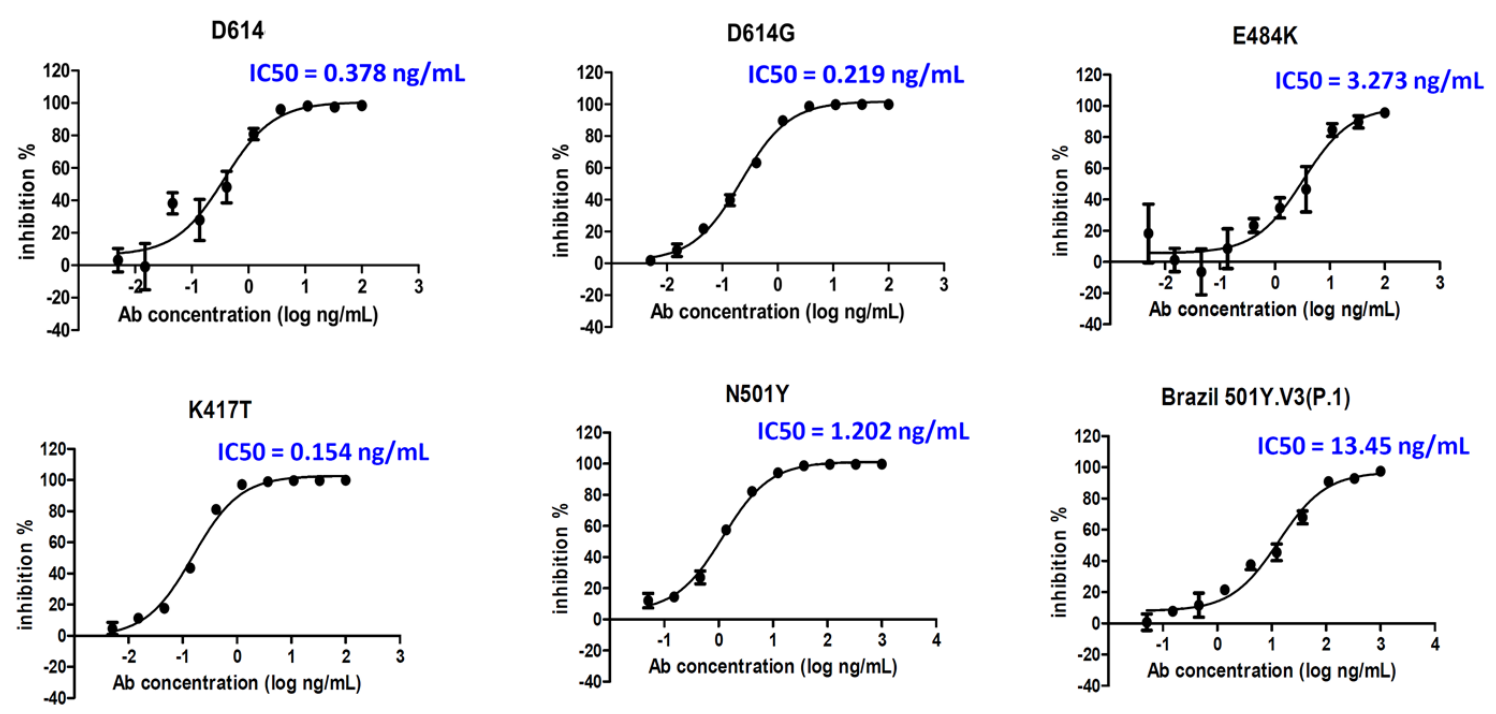

B

Concentration $(\mathrm{ng} / \mathrm{mL})$

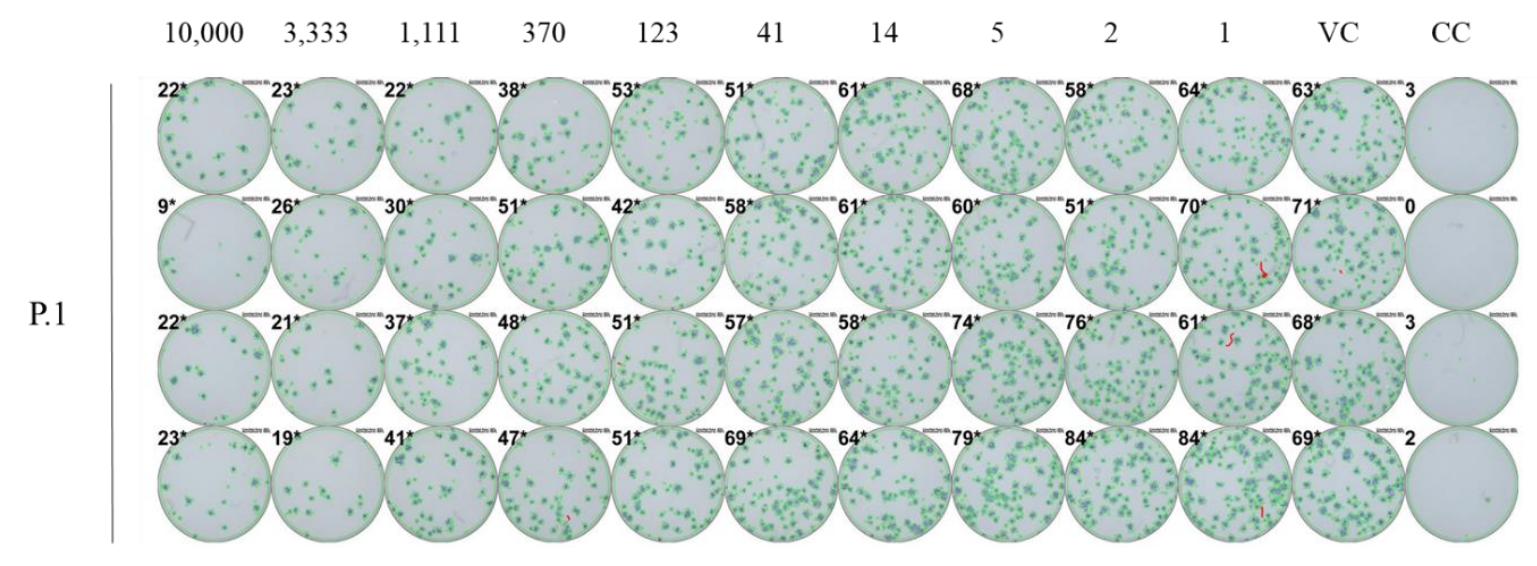

Supplementary figure 2. In vitro neutralization of CT-P59 against P.1. Serially diluted CT-P59 was mixed with indicated variant pseudoviruses for inoculation to ACE2-expressing HEK293T cells. Luciferase activity was measured and \%Neutralization was calculated (A). CT-P59 dilutions were preincubated with P.1 variant. The antibody-virus mixture were inoculated into Vero E6 cells, incubated and probed by anti-nucleocapsid antibody and staining (B). VC and CC represent as virus control and cell control, respectively. 